\title{
HET HELENA-VEEN.
}

Ik weet niet, lezer, of ge wel eens aan de halte Helena-veen uit den trein zijt gestapt, om de kolonie van dien naam te gaan zien, anders zal bet $a$, nadenkende over ' $t$ geen ge zaagt, of beter niet zaagt, op de uitgestrekte vlakte aan weerszijden der spoorbaan op de Noord-Brabant-Limburgsche grens, zeker verwonderd hebben, juist daar een halte aan te treffen.

Uwe verwondering zou echter plaats maken voor waardeering van het doorzicht door de bouwmetsters van den spoorweg aan den dag gelegd, toen zij die halte dáár plaatsten en tevens eene draaibrug bouwden voor een, ja, nu nog denkbeeldig kanaal, maar dat rroeg of laat moet tot stand komen, omdat het bestemd is die sombere Peel, die duizenden hectaren woesten grond, thans nog schaars bewoond, in vruchtbare landouwen te herscheppen, zoo schoon en zoo weelderig als de nijvere hand des ontginners ooit vermocht het aanzijn to geven. Ik bedoel het kanaal, dat door middel van de Noordervaart (Canal du Nord onder Napoleon I geprojecteerd), de boven-Maas en de Zuid-Willemsvaart in verbinding zal stellen met de beneden-Maas en de Waal. Van hoeveel belang die verbinding ware, valt te beoordeelen als men denkt aan de onberekenbare schatten, nu nog grootendeels in den bodem slapende doch die in den vorm van brandstof ten bate der industrie zijn op te delven, om daarna de leegte daardoor ontstaan weer aan te vullen met dat in veen-koloniën zoo gewaardeerde mengsel van straatslik, zand en overgebleven veen, - een mengsel dat vruchtbaar gemaakt met de fæcalia onzer groote steden, welke helaas! nog zoo weinig geteld worden in rergelijking met haar nut, - een teelaarde oplevert zooals de natuurlijke geologie maar zelden aanbiedt.

Wanneer men spreekt van turf als brandstof voor de industrie, pleegt men in de eerste plaats het oog te hebben op de steenfabricatie langs onze hoofdrivieren. Hue belangrijk deco ECUN. 1874. 
moge zijn, meer nog wordt thans die stof roor onze stoomfabrieken bun dagelijksch brood, en de vermeerdering harer productie, zoo die gepaard kan gaan met aanmerkelijke vermindering der productie-kosten, een levenskwestie. De steenkolen-nood moge voor 't oogenblik wat geweken zijn, niets waarborgt tegen eene herhaling, die het getal slachtoffers - men denke aan de suikerfabrieken - waarschijnlijk weder aanzienlijk zou vermeerderen, gezwegen van den invloed dien vracht en prijsverhoogingen op de algemeene welvart in onzen tijd van stoom uitoefenen.

De proeven die reeds genomen zijn om de steenkool door turf te vervangen, hebben den weg aangewezen om het dreigende gevaar te ondervangen. Al zijn die proeven niet overal volkomen gelukt, al is de weg nog ongebaand, het uitgegeven leergeld is niet weggeworpen. De bakens zijn gezet. Men weet waar het euvel ligt, welke bezwaren nog zijn te overwinnen. En weten is kunnen.

Een mijner vrienden albier, een wakker industrieel, deelde mij onlangs den uitalag mede van de door hem genomen proeven:

Hij had het gebruik van turf als brandstof in zijne fabriek, in den loop van 1873 weder moeten opgeven, nadat het van Augustus 1872 met voordeel in praktijk was gebracht. Wèl was gebleken, dat zelfs de zwaarste vuren met het beste gevolg met turf gestookt konden worden, en dat de turf, met uitzondering van het groote volumen, als brandstof reel gemakken boven steenkool annbiedt, maar de dalende prijzen dezer brandstof en de klimmende prijzen van den turf, deden spoedig de balans ten roordeele der steenkool overslaan.

De zaak blijft desniettemin de aandacht overwaardig, omdat z. i. de prijs van den turf bovenmatig stijgt ter wille van het groote volumen en de daardoor hoog loopende transport-kosten. Er zou ook gebrek zijn aan genoegzame concurrentie; anders konden, naar mijn vriend's beweering, de naastbijzijnde turf-producenten, in het Helenaveen, hare prijzen niet ongeveer gelijk houden met dien van den Overijeselsehen turf, hier geleverd. Het gaat, zegt hij, niet aan te veronderstellen dat de voortbrengingskosten van turf in Noord-Brabant zóó oneindig veel hooger zijn dan die in Overijesel, en men moet daarom tot het besluit komen, dat of de Overijsselsche verveeners met verlies willen werken, of dat de Noord-Brabantsche verveeners bun minimam van winst hooger houden dan de Overijsselsche, - iets waarin zij volkomen rrij zijn, maar dat dan het gebruik ran turf in de fa- 
brieken van Noord-Brabant onmogelijk maakt, terwijl het in Overijssel en Friesland gestadig toeneemt.

It laat deze gevolgtrekking gebeel voor rekening van mijn vriend, ofschoon ik beken dat, oppervlakkig beschouwd, de juistheid er van voor de hand ligt. Evenwel mag niet worden voorbijgezien dat het Helena-veen in zijne voortbrenging is beperkt èn door het beperkte van zijn aangekocht terrein èn doordien het zijne schepen nog geen voldoende retourvracht kan geven. Dit zou natuurlijk geheel veranderen wanneer het boven besproken kanaal naar Maas en Waal werd doorgetrokken en in gemeenschap werd gebracht met de boven-Maas bij Venlo.

Intusschen zijn de verkregen resultaten der proeven $m$. $i$. niet onbelangrijk.

De laatstelijk in September en October 1873 op ffinke schaal gemaakte vergelijkingen toonden aan, dat dezelfde arbeidshoeveelheid, die men toen voor $f 100$ met steenkool verkreeg, met turf $f$ 121.84 kostte. Deze proeven werden genomen met overijsselschen turf uit de veenderij van de erven mr. v. Roijen; met Noord-Brabantsche peelturf zoude de uitkomst ter wille van haar nog grooter volume nog iets nadeeliger voor den turf geweest zijn.

Wanneer men nu ziet dat in de som van $f 100,00\left(^{*}\right)$ aan steenkool, slechts begrepen is eene som van $f 19,50$ vervoerkosten, doch in die van $f 121,84$ aan turf $f 82.70$, dan blijkt spoedig $1^{\circ}$, dat voor plaatsen die meer nabij de veenderijen gelegen zijn en waar de verveeners geen buitengewone winstberekening in praktijk brengen, het gebruik van turf als brandstof inderdaad nog zeer voordeelig kan zijn, en $2^{\circ}$. dat het ruim de moeite loonen zoude, wanneer men de middelen zocht en in praktijk bracht, om bet volumen van de turf met om en om de belft te verminderen.

Wanneer toch het volumen met de helft rerminderde, dan zoude het quantum arbeid, dat met steenkool roor $f 100,00$ is te verkrijgen, met turf maar $f 80,49$ kosten. Bij vermindering van het volumen met een derde $f 94,30$. Bij deze laatste sommen zouden natuurlijk gevoegd moeten worden de kosten van bet procédé, wederom verminderd met het verscbil in transportkosten op het terrein van productie.

Men mag verwachten dat de gespannen aandacht waarmedo

(*) Men verlieze niet nit het oog dat deze getallen enkel relatieve waarde hebben en dat zij slechts geldig zijn roor deze fabriek on gelijk gelegenen. 
thans in vele streken het gebruik van turf als brandstof in de industrie wordt gadegeslagen, aanleiding zal geven tot het nemen van afdoende proeven.

Vermindering der transportkosten gepaard aan vermeerdering der productie schijnt mij toe als de spil waar de geheele kwestie om draait.

Daartoe is zeker het boven aangegeven middel van groot belang, doch het is geenszins het eenige. Veel meer rerwacht ik van eene doortastende verbetering der kanalisatie in het gansche land, om het vervoer in groote schepen te bevorderen en om die enorme hoeveelheid reen, die thans nog in den bodem slapende is, geschikt te maken tot exploitatio en bet ontbloote terrein tevens vatbaar voor ontginning.

In nauw verband daarmede staat de brandende fæcalia-kwestie in onze groote steden. Deze raakt waarlijk zeer ernstige algemeene belangen: nijverluid, voeding en hygiène.

Een ander belangrijk voordeel mag voor Noord-Brabant in 't bijzonder verwacht worden van de kanalisatie der Peel. Aanmerkelijke vermindering $\mathrm{nl}$. van het waterbezwaar, waaronder de van nature vruchtbare streek tusschen Grave en 's Bosch lijdt zoowel als de valei welke de rivier de Aa doorloopt evenwijdig met en ten noorden der Zuid-Willemsvaart. Immers 't is eene thans voor goed erkende waarbeid, dat bij drooglegging door kanalisatie of draineering van veenen en woeste gronden, veel meer ruimte tot waterberging wordt verkregen, dan hunne vroegere sponsachtige oppervlakte pleegt te kunnen aanbieden. 't Is daarom ook dat men tegenwoordig bij het beramen van plannen tot waterbevrijding eener streek, in de eerste plaats het oog richt op den oorsprong, op de oorzaak waaruit het bezwaar ontstaat, en door deskundigen, op grond hunner ondervinding, wordt voorspeld, dat van 't oogenblik af aan dat de Peel in exploitatie zal zijn gebracht en geheel gekanaliseerd daardoor bet waterbezwaar voor lager gelegen gronden geheel zal zijn weggenomen.

Waar zóó tastbaar onderscheidene belangen der nijverheid samenvallen, - waar de Staat door het openen van een nieuwen waterweg onmiddellijk zóó aanmerkelijk den nationalen rijkdom kan vermeerderen, door eene bescherming welke de strengsie doctrinair niet zal wraken, bescherming met het doel om de productie des bodems van het eigen land te verhoogen, - om aan noesten vlijt gelegenheid te geven de daarin verborgen schatten in omloop te brengen en te doen strekken tot bevordering van 
andere takken van industrie, - daar zal het wel niet gewaagd schijnen het vertrouwen uit te drukken, dat het doorzicht, warrvan het maken eener draaibrug in den staatsspoorweg voor het nog te graven kanaal door de Peel getuigt, niet lang meer zal worden beschaamd.

Dat zou te meer onverantwoordelijk zijn nu én de ontginningen in de Princepeel bij Mil van de heeren Nering Bögel c.s. de geschiktheid der gronden tot cultuur aantoonen, én de exploitatie van het Helena-veen, onder velerlei opzicbt, bewijst wat energie en overleg vermogen, en hoe aanhoudende omzetting van werkelijk kapitaal, gelijk de sneeuwbal die ran een hoogte rolt, aan eene nederig begonnen onderneming proportiën geeft waarover men verbaasd staat.

Zeide ik straks dat aan de halte Helena-veen behalve de bewuste brug niets waar te nemen is dan een onafzienbare vlakte, lezer, volg mij met uwe gedacbten op eene reis in den jongsten zomer door een vriendenkring gemaakt in gezelschap van den heer Jan van de Griendt, directeur der matschappij, voor wier rekening de verveening en ontginning gedreven wordt, en ras, op een paar kilometers afstand ten westen, zal ik voor uw oog een vrij wat verkwikkender tafereel ontrollen.

Het contrast is frappant als men omtrent een half uur met die eigenaardige voertuigen, op wielen met ongemeen breede velgen, over bet hobbelig met takkenbossen belegd reenpad is gesukkeld, - een sprekend bewijs van het onvermogen der doode hand, (het pad ligt over het eigendom van de gemeente Deurne), om met de particuliere industrie naar den palm der overwinning te dingen, - en als men dan komt aan bet hoofd-kanaal dat in westelijke richting het Helena-veen doorsnijdt tot aan de Noordervaart die ze met de Zuid. Willemsvaart verbindt.

Op eenige honderde schreden ten zuiden ziet ge een veld van 300 hectaren veenboekweit, ' $t$ welk zich aan het oog als een helder wit laken vertoont dat daar ligt uitgespreid en waaruit wasems en geuren opstijgen, die als een verkwikkende balsem de zinnen streelen en verkwikken. Het oog verlustigt zich in dat belder bruidsgewaad, het oor in het gegons van dat bijenheir waar het een juichtoon aanheft, blijde als het schijnt hier bij dit bloemfeest in den mensch een mededinger te vinden op bet veld der nijverheid.

Het gezelschap, nog geheel onder den indruk van het versech 
genotene, gaat vervolgens, bij verkiezing, - want er is ook gelegenbeid om over den barden grintweg die op den zuiderkanaalberm is gelegd te rijden, - op een netten schroefboot over, die tusschentijds als sleepboot gebruikt wordt en overigens bestemd is om het werkvolk met het minste tijdverlies regelmatig naar het werk te brengen en er van daan te halen.

Wat heerlijk gezicht! links en rechts de uitstekende masten der schepen die in de wijken (zij-kanalen) onder lading liggen; voor u in de verte het opdoemen der jeugdige kolonie met 't welig groen der talrijke dreven, waarboven de nette torenspits der kerk uitsteekt, en waartusschen men al voortvarende de nette vriendelijk lachende woningen met bloemtuintjes omkransd ziet, vaak opgevrolijkt door spelende van gezondbeid blozende kinderen. En overal beweging; in alles leven. Het gezelschap, terwijl het zich aan een eenroudig maar smakelijk ontbijt te goed doet, dat van eene aisance getuigt zooals alleen eigen productio die tan aanbieden, gezeten onder een nette tent, tegen de zonnestralen beschermd en in 't genot van het zachte koeltje dat de snelheid aanbrengt, waarmede de boot water en lucht doorklieft, is nauwlijks een ten boorde geladen turfsehip voorbij gestreefd, of daar ontmoet bet een ander dat op zijne beurt een lading gaat ontvangen. Hier en daar ploegen Hanoveranen aan den arbeid, pootige kerels, die bij het turfsteken een door krachtig voedsel onderhouden arbeidsvermogen aanwenden, - een spaarzaamheid en zelfbeheersching toonen, waardoor zij ook op dit nederige veld getuigenis van den ernst komen geven, die den Duitschers overal den weg baant tot physiek en industrieel overwicht.

Hoe meer men de hoofdplaats nadert, hoe vrolijker het gezicht wordt, hoe neer afwisseling het anubiedt. Had men straks als 't ware nog te doen met 't pionierswerk, nu krijgt men geleidelijk de ontwikkeling te bewonderen, verkregen door verdere omzetting van het kapitaal eerst door uitdelving van het veen gevormd, omzetting vooral in den intensieven landbouw.

Wat is hier de natuur, voor 20 jaren nog dor en wild, reeds betoovrend schoon! 't Is bijna ongelootlijk dat menseheu-arbeid zooveel vermocht. Welk verschil tusschen toen en beden! maar ook wat contrast met de duffe stad die we waren ontsneld: hier doordringt ons een plechtige vrede, die over de velden heerscht, en zich meester maakt van geheel ons wezen, zoo zacht dat wij het bijna niet opmerken. Het hart klopt ons stiller en regelmatiger in den boezem; onze adem komt onbelemmerd uit breeder 
borst; de driften zwijgen; de kneuzingen, de wonden, ons in den dagelijkschen worstelstrijd des levens geslagen worden toegetrokken en geheeld; onze zenuwen en spieren, door eer- en geldzucht, door beslommeringen van allen aard, gedurig overrekt, ontspannen zich; ziel en lichaam hernemen hun evenwicht; wij nemen weer bezit van ons eigen zelven.

Het was onder dezen indruk, dat enn naast mij gezeten vriend, het oog op het kloeke gelaat van den ondernemer gevestigd, me in 't'oor fluisterde: „En zoo'n man willen geestdrijvers nu uit den Raad en uit de Staten stooten!"

Wat ik antwoordde weet ik niet meer, maar wel dat ik het de moeite niet waard achtte ons langer door de kleingeestigheden van een Bosschen verkiezingstrijd van het genot te laten aftrekken, dat bier arbeid en natuur, als een rader en eene moeder voortbrachten en te genieten gaven.

Ziet! Hoe prachtig die groene weide afsteekt bij dat purper klaverveld, die sneeuwwitte boekweit in de verte, bij dat gouden graan op den voorgrond; en dan boe majestatisch verheffen zich geene boomen, den stam pijlrecht opbeurende, de takken ten allen kanten uitspreidende gretig naar lucht en licht. Wat overvloed van kleuren! welke afwisseling, welke harmonie!

Zoo droomende en haast voor ik het wist, was de boot zijne aanlegplaats aan 't havenhoofd genaderd. Noode werd bet gezicht van $z 00$ veel schoons afgewend.

Dan genoeg bewonderd; genieten wo verder, door meer de economische zijde dezer schepping te gaan bestudeeren; want wo weten immers dat kennis, onbezweken arbeidzaambeid, overleg en spaarzaanheid ook hier hebben moeten samenwerken om leven en wasdom te onderhouden.

Gewis heeft de onderneming, die in 'tjaar 1852 door van de Griendt en eenige medestanders werd aangevangen, mot veel tegenspoed te kampen gehad. Er is leergeld gegeven, maar nooit nutteloos. Men meende aanvankelijk dat, zoo de noordervaart maar was opgehaald en men van daaruit een kanaal kon graven tot in de peel, die ter oppervlakte van omtrent 1000 hectaren van de gemeenten Deurne en Horst was aangekocht, men met turfsteken kon beginnen. Men had er geen erg in dat de eerste voorwaarden van exploitatie der hooge veenen is de begrepping ter bevordering der doorlegging en samenpersing. $D_{\theta}$ wijken moeten tevens dienen 
voor den gedroogden turf te kunnen verschepen; de weeke veenbodem laat geen ander vervoer toe.

Meende men alzoo reeds "den vogel of te lebben", toen de Minister Thorbecke last gaf tot herstel en bevaarbaarmaking der Noordervaart, en toog men moedig aan 't graven der Helenavaart, ras werd ingezien dat men dasrmede nog niet halfweg kwam.

Onder het voortwerken kreeg men telkens duidelijker den omvang voor den geest die aan de onderneuning moest gegeven worden, zou ze eenmaal de moeite kunnen loonen daraan te besteden, en trad daardoor de behoefte al sterker op den voorgrond aan grooter kapitaal dan de ondernemers aanvankelijk voornemens waren er in to steken.

Niet zonder moeite is dat verkregen. Ook hier hebben afgunst, tegenwerking en verdachtmaking, de geest van denigrement on inertie, hunne rol vervult. Die geest schijat zelfs nu en dan bij ambtenaars te hebben voorgezeten bij de toepassing van vrijdommen volgens de vrijgevige wet van 1840 , tengevolge waarvan deletter wel eens zwaarder moet gewogen hebben dan het "favores sunt ampliandi."

Gelukkig heeft de wetgever bij de codificatio van 26 Mei 1870 van ruimer inzicht doen blijken.

Eene belangrijk schrede was intusschen voorwaarts gezet door de onderneming der boekweitteelt, waartoe een veld van 800 hectaren van de Limburgsche gemeente Horst werd in huur genomen. De winsten hieruit verkregen, hebben de onderneming aanmerkelijk onderschragad; daardoor werd het noodige kapitaal verkregen - waarmede de ondernemers met onbezweken moed als echte schansgravers de voor het groote publiek nog onvruehtbaar schijnende kanalisatie en begrepping voortzetten.

Bij de oprichting der naamlooze vennootschap onder de benaming van Maatschappij lot ontginning en verveening der peel genaamd Helena- $V_{e e n}$, was de grootste pijn reeds geleden. Toch was de oprichting eener vennootschap een verstandige matregel, onder velerlei opzieht.

De onderneming was voor een burgerlijke maatschap te omvangrijk, te zeer gecompliceerd, - zij moest ook van meer duurzaamheid verzekerd worden dan op de gewone manier van associatio was te verkrijgen.

Voor de nieuwe maatschappii was het van overwegend belang, dat als grootste aandeelhouders de oorspronkelijke ondernemers optraden en een hunner, de reeds genoemde heer J. van de Griendt, die met zijn broeder $\frac{3}{5}$ der aandeelen nam, het Directeurschap aan- 
vaardde. Het eigen belang der directie werd zoo doende nauw met dat der vennootschap rereenigd.

In de gansche onderneming is dan ook de invloed der practische hand zichtbaar, overal ziet men het spreekwoord bewaarheid „dien de koe toehoort," enz.

Veel beeft ook de te vroeg overleden Dekkers, die met het dagelijksch bebeer der werkzaambeden van den aanvang af belast was, tot het welslagen bijgebracht.

Nooit heb ik een man ontmoet bij wien juist economisch doorzicht meer aangeboren was. Bij bem proefnemer bij uitnemendheid, stond nauwkeurige waarneming, strenge boekhouding, in alles wat hij beproefde op den voorgrond. Geen tak van het veelomvattend bedrijf, waarvan de verschillende uitkomsten niet waren nagegaan en becijferd, waarvan niet alles was geteld en gewrogen : in de verveening zoowel als in de ontginning, in land- en tuinbouw, in hout- en veeteelt, voor laden en lossen, voor spitten on ploegen, in een woord voor alle werk had hij uit de verkregen uitkomsten balancen opgemaakt waaruit de tarieven zijn kunnen getrokken worden, waarnaar alle arbeidsloon tegenwoordig nog wordt berekend; daghuur is geheel afgeschaft; niet do duur, maar de waarde van het werk komt in aanmerking.

Hem dankt ook de jeugdige kolonie het volstrekt weeren van sterken drank, wat op eene vaste bevolking nu reeds tot 400 zielen aangegroeid en een 100tal schippers, geene kleinigheid moet geweest zijn, doch wat, nu die onthouding in de zeden der kolonisten is doorgedrongen, door die bij de honderd alleen van arbeid bestande betrekkelijk welvarende gezinnen dankbaar wordt op prije gesteld.

Het was dan ook niet te verwonderen dat de directie bij tijds bedacht was op de ankweeking van een plaatsvervanger indien de kundige man haar eens ontriel. „Dat moest, naar van de Griendt's eigenaardige zegswijs, een jongen zijn van den kouden grond "geen fijne beschuit."

De tegenwoordig met het beheer in het veeu belaste opzichter doet eer aan zijn voorganger, door de wijze waarop hij zijn voetspoor volgt in de uitoefening zijner veelomvattende taak.

Veelomvattend inderdaad, men zal dit eenigszins kannen afmeten uit de volgende bijzonderheden :

Verveening.

De jaarlijksche productie van turf wordt geschat op 1600.000 
hectoliters $(800,000$ ton). Behalve voor begreppen en voor onderboud van 't hoofdkanaal en de wijken, reeds ter lengte van 29950 meters, met bruggen en grintwegen, wordt daartoe eene uitgaaf van $f \quad 60.000$ voor arbeidsloon gevorderd.

Reeds is er op gewezen dat in den zomer Duitsche turf gravers moeten worden aangeworven om in de noodige ardeidskracht voor de opgegeven productie te voorzien. 't Is duidelijk dat de schaarschte aan werkvolk nadeelig. werkt zoowel op productie als op productiekosten.

Met bijzondere belangstelling nam ik kennis van een plan dat in het jaar 1871 tot een begin van uitwoering genaderd scbeen te ziju. Het verslag in de algemeene vergadering van aandeelhouders in April 1871 uitgebracht, bevat dienaangaande de volgende merkwaardige mededeelingen:

„Nog makk ik mij deze gelegenbeid ten nutte mededeeling te „doen van het door mij, aan het Bestuur, vóór eenige maanden, in "overweging gegeven denkbeeld tot oprichting voor rekening der "Maatschappij, van een beetwortelsuikerfabriek in Helena-veen.

„De gronden die mij hiertoe geleid bebben wil ik in 't kort ,vermelden.

"Ondanks de omstandigheid dat het bouwland der Maatschappij "vooralsnog ongéschikt wordt geacht tot de teelt der beetwortelen, "zoude een suikerfabriek in het Helena-veen groote voordeelen „aanbrengen.

„In de eerste plaats heeft eene dergelijke fabriek jaarlijks voor „een bedrag van $f$ 15,000 brandstoffen noodig; hiertoe stelde ik „mij voor te bezigen den afval of stukken turf thans minder goed "leverbaar en jaarlijks ongeveer tot eene hoeveelheid van 100,000 "tonnen in de Veenderij voorkomende.

„Ten tweede levert het aanvoeren der beetwortelen in den na"tijd belangrijke retourvrachten én voor eigene én voor vreemde "schepen; hierdoor wordt tevens voor de laatsten opgeheven het "beletsel, dat deze thans van onze vaart terughoudt: bet gebrek „aan genocgzame retourvracht. De eigene schepen zijn in staat "om het grootste gedeelte van de benoodigd zijnde beetwortelen "aantevoeren, men is dan niet zooals elders afhankelijk van de „dikwerf bovenmatige eischen van de schippers.

„Ten derde vallen de werkzaamheden eener dergelijke fabriek „juist in den tijd (de maanden October, November, December, „Januari en Februari), dat die ophouden in de Veenderij, zoodat „,eene eenigszins gezochte, niet altijd voordeelige, werkverschaffing 
"wordt vermeden, terwijl ook niet alleen uitbreiding van het ge„tal inwoners, maar vooral de restiging eener beter ontwikkelde „en meer welvarende bevolking in de Veenderij in hooge mate „zoude bevorderd worden, daar het personeel aan eene suikerfa„briek verbonden, vrij annzienlijk is.

"Ten vierde zoude de verkoop van pulpe in die streken, waar „juist zooveel gebrek aan veevoeder is, veel meer dan elders be„langrijke voordeelen afwerpen.

„Ook de schuimaarde en verdere afval, heeft in de Veenderij „meer nut dan op andere plaatsen, voor de ontginning van uitge,Feend land.

„Eindelijk de zekerheid dat dergelijke fabrieken, goed ingerigt "en door bekwame handen bestuurd, groote voordeelen moeten „opleveren.

"Door het Bestuur werd bereids onderzoek op eenige plaatsen „gedaan, en is het dan ook reeds door vertrouwde informatiön tot "de overtuiging gekomen, dat de vestiging eener dergelijke fa„briek ten zeerste aanbeveling verdient en meer dan verdubbeling „van dividend zoude te weeg brengen.

„De reden waarom echter het Bestuur vooralsnog geen bepaald "voorstel hieromtrent zal doen, ligt minder in den niet te ontken"nen omvang der zaak, noch in de moeijelijkheden en zorgen daar"aan noodwendig verbonden, maar meer in de $z$ warigheid om thans "op voordeelige wijze te verkrijgen het daartoe benoodigde kapitaal, "wat op ongeveer $f \mathbf{2 5 0 . 0 0 0}$ geraamd wordt."

"Zoodoende, voegde v. d. Gr. er aan toe, hadden we geregelder omzet van ons kapitaal gekregen, en daar we met eigen kapitaal zouden gewerkt hebben, vele klippen kunnen veruijden waar in 't algemeen onze suikerfabrieken op stranden, dat zijn: duurte der brandstoffen, te hooge vrachten, en ten deele ook de rentelast van 't bedrijfkapitaal gedurende den langen tijd in 't jaar dat het bij hen slaapt."

En waarom hebt ge dat plan niet doorgezet? vroeg ik verwonderd. „Och, was 't antwoord, onze aandeelhouders zijn heel sekure lui, die er over schenen te denken als den boer van Bakel (*), die zijn dorp veel booger schatte dan Amsterdam, omdat er nooit jemand bankroet was gegaan."

Kon de renteniersgeest scherper geteekend worden?

Een ander middel, dat wel langzamer werkt maar nog zekerder,

$\left.{ }^{*}\right)$ Een der minst ontwikkelde dorpen van Noord-Brabant. 
om de gevestigde bevolking te versterken brengt mij tot bespre. king van :

\section{De ontginning en den landbouw.}

Afgescheiden van de reenboekweit-teelt, die noodzakelijk door de herhaalde veenbranding sterk gaat verminderen, (over't jaar 1874 wordt nog slechts op eene productie van ruim 3000 hectoliters gerekend) heeft de maatschappij reeds 108 hectaren tot bouw-en weiland en 30 hectaren tot dennenbosch ontgonnen.

De ontginning geschiedt door vermenging van het nog overgebleven bovenveen op het van turf ontbloote terrein, met een laag van $0,10 \mathrm{M}^{\prime}$ zand; de bemesting verder met straatslik.

In later jaren wordt de bemesting voortgezet met (*), beer". Op die wijs worden nu elk jaar 10 hectaren nieuw bouwland verkregen, tot alle cultuur geschikt, 't geen nader zal blijken uit de vermelding der verkregen opbrengsten.

„Kon ik maar meer van dat goed krijgen! herhaalde v, d. Gr. telkens, bet zilver er voor uitgegeven, komt als goud terug." Dat woord van dezen practicus mochten de Gemeenteraden van onze groote steden wel eens ernstig ter harte nemen, bedenkend wat het zeggen wil: perken te stellen aan de verontreiniging van water en lucht in 't hygienisch belang der bevolking on te gelijk de voedingsmiddelen des volks aanmerkelijk te doen toenemen!

Als eerste gewas op ,goed gemaakte" grond, - zoo is de gemeene term - worden in den regel aardappelen verbouwd; eene voordeelige schaar, als, gelijk in 1873 , een opbrengst van 300 bectoliters per bectare kan worden verkregen, dat is op 10 hec. taren tegen $f$ 2.- per hectoliter 3000 hectl. $\times f 2 .-=f 6000$

Rekent men $\mathrm{nu}$ voor bewerking, bemesting en verder arbeidsloon $f$ 900.-, per hectare: $10 \times f 900$. . per 9000 dan heeft men een te kort van $f 3000$ doch dan komt de maatschappij voor $f 300$. - per hectare in ' $t$ bezit van uitstekenden bouwgrond, die na het 5 de jaar telkens door hemesting verbeterd, reeds, - nu nog gezwegen van den vlas- en tabaksteelt - een netto rendement van $f$ 200. - kan opleveren.

De Maatschappij handelt verstandig door de goedgemaakte gron-

(*) $1 \mathrm{k}$ gebruik dit woord opzettelijk in plaats van facalia; de stof mag waarlijk wel met haar eigen naam genoemd worden als men ziet wat ze hier vermocht uit te werken. 
den, slechts tegen den kostenden prijs der ontginning op haren balans te brengen. Het ware te wenschen dat door alle naamlooze vennootschappen zoo voor het intact blijven van het kapitaal werd gezorgd : het leed zou dikwijls niet zoo naamloos groot worden.

Intusschen moet de innerlijke waarde, met het oog op de volgende productie gewis veel hooger geschat worden:

16.27 hectaren rogge opbrengst $=24$ hectol. per hectare (*)

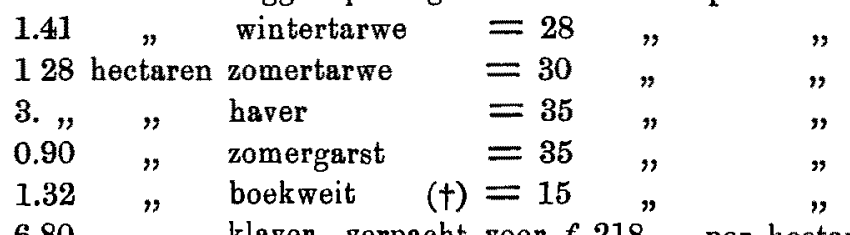

$6.80 "$ klaver, verpacht voor $f$ 218.- per bectare.

Het verbouwde door particuliere kolonisten op gehuurde gronden van de maatschappij is weinig minder.

Ik herbasl, het is verstandig op die manier de nadeelen van het absentiïsme, - zoo noemt van de Griendt het gevolg der uitkeering van dividend aan de aandeelhouders, - voor de kolonie wat te temperen. "Het kapitaal moest hier kunnen blijven" voegde bij me toe, "dan zou bevolking en welvart nog veel sterker aangroeien en de koopwaarde der gronden in evenredigheid komen met hun productief vermogen."

Zulke ruime denkbeelden bij een actionnair zijn waarlijk niet alledaagsch. En, dat denken en handelen ook hier niet ver van elkaâr verwijderd zijn, daarvan overtuigde mij de volgende mededeelingen :

"Het plan bestaat om aan onze menschen gelegenheid te geven hunne spaarpenningen rentegevend in eene spaarbank to brengen en om tevens een soort hypotheekbank te vormen. De ongemeen gunstige resultaten van de tabaksteelt en de vlasbouw geven n.l. gelegenheid den halfbouw meer in toepassing te brengen, om zoo doende den kolonist in de voordeelen der ondernoming te doen deelen ten bate der onderneming zelve. Met die overwinst, gespaard en vermeerderd met rente, moet hij allengs eigen geërfde kunnen worden, waarin hem de hypotheekbank moet helpen door de betaling der koopsom in annuiteiten open te stelleu."

De cultuur van vlas en tabak is ook uit een algemeen land. bouwkundig oogpunt de bijzondere aandacht overwaardig.

(*) en 350 kilogr, stroo. De tweede vruchten worden hier buiten aanmerking gelaten.

(†) Geen veenboekweit. 
De tabak stond toen ik daar was, nog in zijn vollen groei. Welk een heerlijken aanblik bood dat veld aan van 2 hectaren met die weelderige tabaksplanten bezet! frischer en rerkwikkender, alhans voor den economist, dan de kunstigste bloembedden. En hoe wordt de herinnering daaraan niet aangenaam rerlevendigd nu ik verneem dat de uitkomst van deze proef is geweest: opbrengst van 2 hectaren: 6445 kilogr. verkocht tegen $f 62$. - per 100 kilogr. $=f 3995.90$.

van deze bruto opbrengst . . . . . . . . . $\pm f 4000.00$ komt als aandeel der planters ( 2 gezinnen) in den halfbouw $\frac{1}{2}$. . . . . . . . . . . . . . ., 2000.00 per bectare . . . . . . . . . . . . . . . $\frac{\frac{f 2000.00}{f 1000.00}}{.}$ voor bemesting en rente der schuur . . . . . . „325.00 Blijft zuiver per becfare. . . . . . . . . . . $\frac{f 675.00}{f}$

Dat heet kolven! En waarin ligt nu bet geheim van die prachtige uitkomst? Eenroudig in den "beer" en het straatslik uit 's Hertogen bosch.

In 1873 is in Helena-veen roor het landbouw-bedrijf in 't algemeen angevoerd: 1400 stères „beer", door de onderneming zelve, die daarvoor eene bijzondere dienst in de stad heeft ingespannen: berekend met de vracht tegen $f 4$ per stère $=$. . I 5600.00 en 5000 stères straatslik dat komt op $\left(^{*}\right) f 1.50$ per stère, 7000.00

Met die uitkomsten voor oogen wordt men zonderling te moede als men daarbij nadenkt dat die zelfde oude Hertogstad, zoo prat op dien titel, gewis het drievoudige dier waarde, tot groot nadeel der volksgezondheid in de Dieze, wier water bij onvoldoende spuiing sterk wordt verontreinigd, laat wegvloeien.

\section{De Vlasteelt.}

Op 9 hectaren is gewonnen 6120 kilogram vlas en 81 bectoliter lijnzaad ter waarde van ruim $f 7000(\dagger)$. Het behoeft niet opgemerkt dat best zaaizaad door de maatschappij is anngekocht, wetende wat voordeel, vooral in deze cultuur daarvan te wachten

(*) Het straatslik is voor de ontginning onmisbar; als mest heeft het overigens weinig waarde; men rekent zoo wat 70 cents per stère.

(†) 6120 kilo a $f \mathrm{l}$ per $\mathrm{k} .=f 6120.00$

81 hectol. lijnz. à $f 12.50=" 1012.50$

$\overline{f 7182.50}$ 
is, en evenmin dat voor uitstekende werktuigen ter bereiding is gezorgd, maar wat de moeite ward schijnt te vermelden, is de uitnemende geschiktheid die de peel met hare rroeger gegraven wijken aanbiedt om op onkostbare wijze het vlas te weleren (ter rotting te leggen); ook de kleur, waarvoor men eerst nog al bevreesd was, is naar het oordeel van kenners puik. Dit wordt dan ook bevestigd door de bedongen prijzen: gemiddeld I f 2.50 per steen van 3.8 kilogram.

Zoo men op de verkregen opbrengst let, valt bet dadelijk in 't oog hoeveel gelegenheid de velerlei bewcrking die het vlas moet ondergaan aanbiedt om daarbij de ,part du lion" - wat zoo zelden gebeurt - ook eens an den arbeid te laten. En dat is juist grootendeels geschilkt winterwerk, waardoor nu de ongewenschte schofttijd van de bewoners kan worden ingekrompen om gaandeweg bij uitbreiding van vlas- en tabaksteelt plaats te maken voor regelmatige en afwisselende bedrijvigheid in alle tijdperken des jaars, - voor ongestoorde roortbrenging.

Ik zou te laagwijlig worden wanneer ik de schets verder getrouw wilde afwerken. Ik zou dan nog moeten spreken van dien prachtigen veestapel van wijlen den heer Dekkers, van zijn tuin en boomgaard ruim voorzien van de fijnste ooftboomen, en hoe dat alles er welgedaan en lieflijk uitzag, zoodat van de Griendt met recht mocht zeggen: „de goede man maakte hier alles vet: grond, runderen, schapen, kalkoenen, kippen, zijn tuin, zijn vrouw, zijne kinderen en - last not least - ook zich zelf." En 't was geen wonder waar alles zoo weelderig groeit en bloeit in die vrije, frische lucht, in die vrolijke bezigheid.

Vrij en vrank is hier het leven; echt Amerikaansch, zonder bestuur of politie van buiten, en toch zoo ordelijk en vredelievend, dat de meest verstokte en bemoeizieke autoriteitsman hier ras van het deugdelijke van zoodanig "Self-government" overtuigd zoude worden.

De gemeente Deurne, waaronder Helena-peen ressorteert, heeft dan ook geen last van de zich zelve besturende kolonie; zelfs in 't onderwijs, dat overal voldoende van overheidszoege moet gegeven voorden, voorziet nog ten deele de onderneming; armlast is onbekend, dank de voorzorg waarvan een onderling gevormd weduwen- en zieken-fonds getuigt. Het moet dan ook wel bevreemden dat de hoofd-gemeente zoo luttel belangstelling toont en zelfs een strijd van belangen wil opwekken, waar eendracht macht is en tot beider poordeel zou gedijen. 
Ik vergat nog te zeggen dat eveneens de kosten der eeredienst, van roomschen en gereformeerden, buiten de lands tractementen, van rector en predikant, door de kolonisten zelven worden gedragen. En dat vrijheid niet schaadt aan godsdienstzin blijkt hier op nieuw uit het plan om weldra eene nieuwe roomsche kerk en pastorie te doen verrijzen, welke gebouwen niet zullen onderdoen voor de nette hervormde kerk en predikantswoning. Dus ook in dit opzicht is Helena-veen - niet 't minst van wege de verdraagzaamheid in 't godsdienstige, - van een Amerikaanschen geest door trokken. Even als de pionnier dáár - gelijk Laboulaye vertaalt, "partout où il s'établit apporte avec lui l'église, l'école, le journal et la banque; car ce sont les quatre elements de toute société chrétienne qui vit de son travail, qu'elles sortent de terre, pourvu qu'on ne les écrase pas." (*) Zoo ook hier; doch men zou niet verwachten in een jonge kolonie buitendien reeds een Telegraafkantoor aan te treffen, dat in rechtstreeksche verbinding staat, zoowel met het kantoor der Directie in den Bosch als met het telegraaf-net de Staatspoorweg-maatschappij. Het is al weder een bewijs van het juist economisch doorzicht der directie en van haar besef dat "tijd is geld."

Dit brengt mij tot de beschouwing van

\section{De scheepvaart.}

Dit is zeker wel de moeilijkste tak van het omvangrijke beheer, ook omdat het oneigenlijk daartoe is moeten gebracht worden. Wanneer het kanaal eenmaal zal zijn doorgetrokken, verbonden met boven- en beneden-Maas en de Waal, dan zal ongetwijfeld de tijd spoedig aanbreken dat de maatsehappij alle krachten op haar eigen gebied onverdeeld zal kunnen inspannen en van het voordeel der arbeid-verdeeling nog meer profiteeren. Gebrek aan genoegzame retourvrachten op haar nu alléén nog met de Zuidwillemsvaart verbonden vaart dwong niet alleen ou schippor, maar ook ondernemer van sleepdiensten en scheepstimmerman te worden.

$\mathrm{Om}$ die vloot van 30 schepen waarvan het grootste 130 ton meet, nu regelmatig te dirigeeren naar de behoefte aan turf van de verschillende steenfabrieken, waarvoor die hoofdzakelijk dient, en met het oog op de stoomsleepdienst zoowel als tot regeling van de ongestoorde lossing en lading der schepen, is do

$\left(^{*}\right)$ Revue des Deux mondes 15 Oct. 1873 bl. 737. 
Telegrafische gemeenschap met het hoofdkantoor onmisbaar. Daarbij komt het groote voordeel eendeels gelegen in het uitsparen van schrijfwerk, ten andere in de regelmaat, waarmede na telegrafische gedachtenwisseling dadelijk in alles kan worden beslist en gehandeld. Dat maakt slender en sleur eenvoudig onmogelijk.

Handelen, zonder er veel over te praten of te schrijven, "niet kakelen zonder eijers te leggen", dat is van de Griendt's leus. Me dunkt zoo'n enkel spreekwoord teekent den eenvoudigen en toch zoo schranderen man beter dan ik het op andere wijs zou kunnen.

Aan het slot van deze verhandeling acht ik het overbodig nog verder de groote voordeelen samen te vatten, die zouden gelegen zijp in eene flink doorgezette kanalisatie, zoowel voor de industrie in ' $t$ algemeen als voor de ontwikkeling van den rijkdom des bodems; doch ik mag enkele van v. d. Griendt's praktische opmerkingen niet over het hoofd zien, 't zijn deze: bij het ontwerpen van kanalisatie-plannen moet men niet 't eerst het oog hebben op de ontginning van schrale heidegronden : "hun tijd is nog niet gekomen;" een kanarl moet tot middel dienen om goedkooper datgene te vervoeren wat bodem en nijverheir eener streek dadelijk kunnen opleveren, en wederkeerig - want tusschen af- en aanvoer is noodwendig verband - om datgene aan to brengen waardoor bodem en industrie beiden in hun productief vermogen worden rersterkt. Zoolnng de reeds ontgonnen gronden gemiddeld nog slechts $\frac{1}{2}$ opleveren van 't geen bij eene doelmatige intensieve cultuur vooral door bemesting is te verkrijgen en nog schatten in de reenstreken als voor de hand liggen, mag aan eene ontginning van heidegronden door andere middelen dan die de natur zelve aanbiedt niet gedacht worden; eerst wanneer de dennenbossohen, die bij doelmatige bewerking op de heide kunnen groeien, zoo ver zijn dst er aan afvoer gedacht kan worden en van zelfs ook aan aanvoer, eerst dan zal hun tijd zijn gekomen. Er moet eerst kapitaal zijn, voor dat aan middelen tot vermeerdering door vervoer en omzetting kan gedacht wordun.
den Bosch, April 1874
W. A. Coolen. 
OPGAVE van de hoogste en langste Coursen van de onderstaande Effecten aan de beurs te Amsterdam.

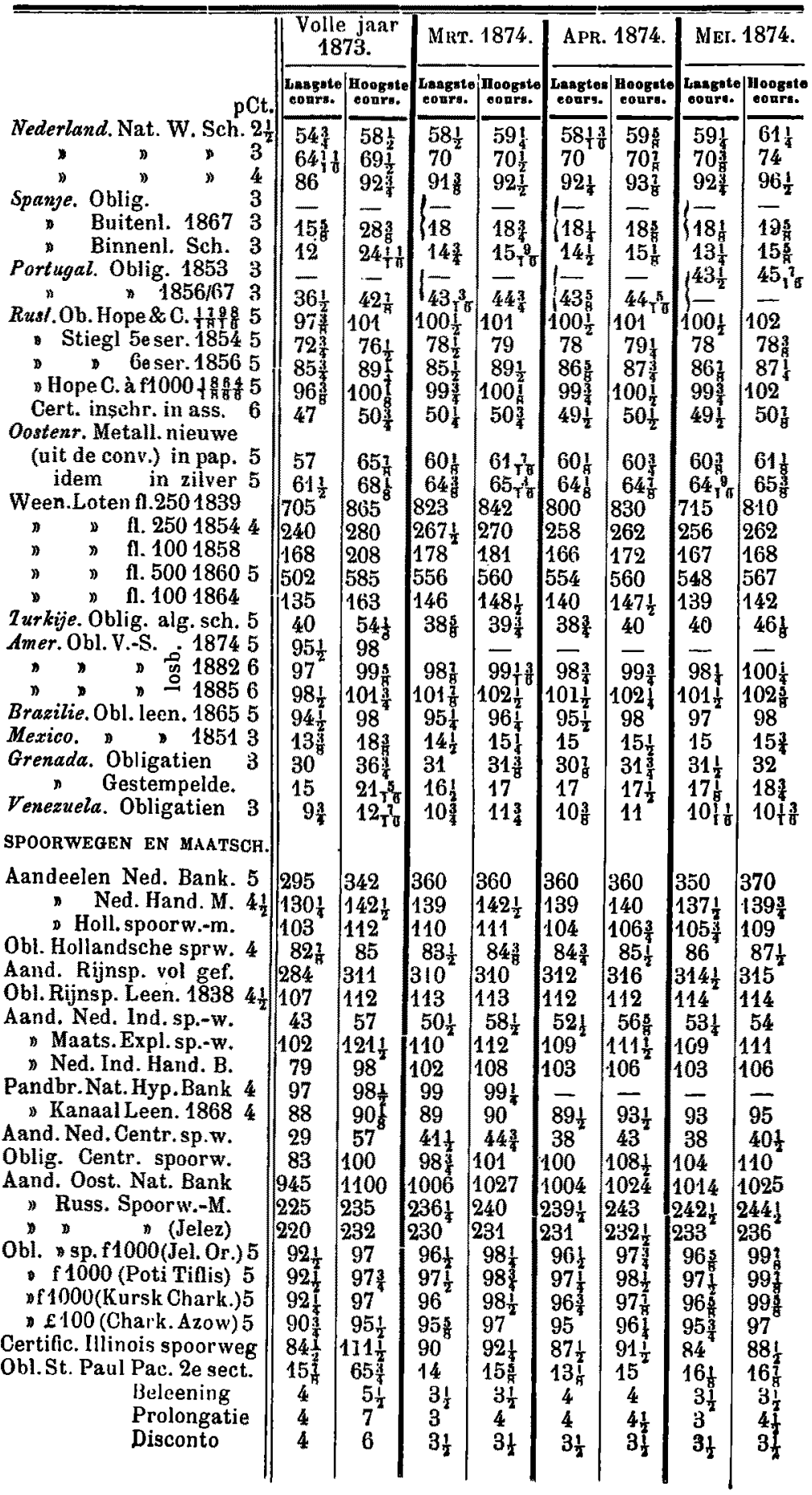

